\title{
Effect of variable content of organic matter and carbonates on results of determination of granulometric composition by means of Casagrande's areometric method in modification by Prószyński
}

\footnotetext{
Abstract: The paper discusses the issue of the admixtures' effect on results of granulometric composition determinations by Casagrande's areometric method in modification by Prószyński. An experiment was conducted involving preparation of samples with known granulometric composition and determination of their composition by means of the aerometric method. Three types of samples were prepared: base (control), containing organic matter, and containing carbonates. Results of the determinations showed a considerable effect of the admixture of organic matter and calcium carbonate on the accordance of determinations, depending on their percent content. The study results also confirmed known dependencies of disturbances in proportions between the sandy and silty-clayey fraction. A practical conclusion from the research is the determination of the threshold of the organic matter and carbonates percent content at which the determination should be absolutely preceded by processes of mineralisation and decalcification.
}

Keywords: aerometric analysis, sedimentation methods, Prószyński's modification, organic matter, carbonates, suspension

\section{INTRODUCTION}

Research on the soil granulometric composition is one of the basic analyses performed by pedologists (Bartkowiak 2011, Lasota et al. 2014, Musztyfaga and Kabała 2015), geologists (Frankowski and Grabowski 2006, Lejzerowicz and Wysocka 2016), as well as physical geographers (Sewerniak 2008, Szymański and Skiba 2007, Braun 2010). The determination of the contribution of particular ranges of grain sizes is among the basic characteristics of soil analyses (Drzymała and Mocek 2004, Różański 2010, Braun 2011). The granulometric composition determines physical properties of the soil (Zawadzki 1999, Brogowski et al. 2014). Due to the importance of this parameter, sizes of fraction classifications, as well as division of soils into granulometric groups have been continuously developed (Polish Soil Classification 2011).

The determination of the grain composition of formations is a multi-aspect issue. Therefore, a number of methods of its determination have been developed, based on different assumptions, among others centrifugation method, pipette method, Atterberg's method, and flow-based method (Ryżak et al. 2009). They are various, and their number is still increasing, following the achievements of technique. The number of applied methods of grain composition analyses is estimated for approximately 400 (Loveland and Whalley
2001). Automated methods currently gain popularity. They employ electronic equipment and computing power offered by computers (among others the method of spectroscopy with photon correlation and method using the phenomenon of laser diffraction). In addition to modern methods, methods with methodical assumptions developed a long time ago and considered universal by many researchers are relatively commonly applied (Orzechowski et al. 2014). One of them is Casagrande's areometric method commonly used in Polish soil studies (Gworek et al. 2000, Konecka-Betley 2009, Licznar et al. 2009, Kabała et al. 2010). The author of the method is Bouyoucos, but because Cassagrande introduced numerous modifications, the method is named after him. Archival results of granulometric analyses obtained by the areometric method are the primary information on grain composition in soil-agricultural maps and their annexes.

The version of the areometric method applied in Poland was developed by M. Prószyński and is more than 50 years old (Prószyński 1949). The author did not explain the methodical aspects and the way of performing the determination in detail. Part of the procedure is based on certain traditions of performing measurements. The basic problem in the method is the determination of the variability of the density of the particle deposition medium, depending on the variable grain size composition of formations. It can result from the natural variability of shares of particular 
size ranges of mineral grains or presence of admixtures such as carbonates, organic matter, iron compounds, etc. The objective of this paper should also be perceived in this context. It involves the determination of the effect of the content of organic matter and calcium carbonate on the credibility of determination of grain size composition by means of Casagrande's areometric method in modification by Prószyński.

\section{STUDY MATERIALS AND METHODS}

The effect of organic and carbonate admixtures on the determination of grain size composition was analysed through conducting controlled experimental measurements with the application of samples with known granulometric composition and secondary samples developed by adding specified amounts of organic matter and carbonate admixtures. They were subject to grain size composition analysis by means of Casagrande's areometric method in modification by Prószyński, and by means of the sieve-weight method. The results were compared to control samples (not containing admixtures).

The analyses involved a new classification of granulometric fractions (Polish Soil Classification 2011). The exceedance of the threshold of $1 \mathrm{~mm}$, original for Prószyński's method (subfraction of very coarse sand $2.0-1.0 \mathrm{~mm}$ ) was related to the presence of the fraction of coarse sand in the areometric analysis. Part of the laboratories still restrict Prószyń- ski's method to a range below $1 \mathrm{~mm}$, some of them expanded the analysis by the aforementioned range. The effect of an additional portion of rapidly deposited soil particles on the deposition of dust and silt particles can be linked to the effect of sand as such (time of deposition of very coarse sand amounts to several seconds). For fractions of sand, irrespective of areometric analysis, the sieve-weight method should be applied. The effect of very coarse sand can be manifested in a certain change in sedimentation conditions, but the key methodical issue in the areometric method is the determination of the effect of the finest fractions on the coarser ones, as presented in Prószyński's charts, ordered by variable contents of the finest fractions.

The experiment was divided into two stages: preparation of material and samples, and proper measurement by means of the areometric method. First, fractions of sand with known subfraction content were prepared for testing (Table 1). Quartz was selected as sample material. It is the least chemically active, quite durable, and simultaneously natural material. Sand was dried and divided into subfractions by means of sieves. The process employed a shaker and a set of sieves (with mesh: 2, 1, 0.5, 0.25, 0.1, $0.05 \mathrm{~mm}$ ). The shaking time amounted to approximately 10 minutes. In order to fraction the material as accurately as possible, manual sieving was also performed on sieves with predefined grain diameters. Such prepared material provided the basis for the

\begin{tabular}{|c|c|c|c|c|c|}
\hline \multirow{2}{*}{$\begin{array}{l}\text { Content of } \\
\text { sand fraction } \\
\text { total } \\
(0.05-2.0 \mathrm{~mm})\end{array}$} & \multicolumn{5}{|c|}{ Content of sand subfractions } \\
\hline & $\begin{array}{l}\text { very coarse } \\
\text { sand } \\
(1-2 \mathrm{~mm})\end{array}$ & $\begin{array}{l}\text { coarse } \\
\text { sand } \\
(0.5-1 \mathrm{~mm})\end{array}$ & $\begin{array}{l}\text { medium } \\
\text { sand } \\
(0.25-0.5 \mathrm{~mm})\end{array}$ & $\begin{array}{l}\text { fine } \\
\text { sand } \\
(0.1-0.25 \mathrm{~mm})\end{array}$ & $\begin{array}{l}\text { very fine sand } \\
(0.05-0.1 \mathrm{~mm})\end{array}$ \\
\hline \multicolumn{6}{|c|}{$\%$ of the entire sample } \\
\hline 100 & 5 & 25 & 40 & 25 & 5 \\
\hline 98 & 4 & 19 & 43 & 25 & 8 \\
\hline 96 & 4 & 18 & 43 & 25 & 8 \\
\hline 94 & 3 & 16 & 45 & 23 & 8 \\
\hline 92 & 3 & 15 & 45 & 23 & 8 \\
\hline 90 & 1 & 14 & 50 & 18 & 8 \\
\hline 87 & 1 & 11 & 30 & 35 & 10 \\
\hline 85 & 1 & 10 & 29 & 35 & 10 \\
\hline 80 & 1 & 13 & 13 & 38 & 17 \\
\hline 70 & 1 & 5 & 8 & 38 & 20 \\
\hline 67 & 1 & 5 & 8 & 38 & 17 \\
\hline 65 & 1 & 3 & 5 & 38 & 20 \\
\hline 45 & 0 & 0 & 0 & 30 & 15 \\
\hline 25 & 0 & 0 & 0 & 20 & 5 \\
\hline 5 & 0 & 0 & 0 & 0 & 5 \\
\hline
\end{tabular}

TABLE 1. Grain size composition of sand fractions (prepared samples) 
preparation of samples. To supplement control samples (first group: 15 samples), a specified content of a mixture of the silt and clay fraction with a grain diameter below $0.05 \mathrm{~mm}$ (according to classification PTG 2008) (Polskie Towarzystwo Gleboznawcze 2009). The material was obtained as residue from sieving fractions with larger grain diameters (Table 2).

TABLE 2. Grain size composition of prepared samples

\begin{tabular}{|c|c|c|c|c|}
\hline \multirow{3}{*}{$\begin{array}{l}\text { Granulo- } \\
\text { metric } \\
\text { group }\end{array}$} & \multicolumn{2}{|l|}{$\begin{array}{l}\text { Control } \\
\text { samples: (\%) }\end{array}$} & \multicolumn{2}{|c|}{$\begin{array}{l}\text { Samples } \\
\text { with admixtures }\end{array}$} \\
\hline & \multirow[t]{2}{*}{$\begin{array}{l}\text { sand } \\
(2-0.05 \mathrm{~mm})\end{array}$} & \multirow[t]{2}{*}{$\begin{array}{l}\text { silt and clay } \\
(<0.05 \mathrm{~mm})\end{array}$} & $\begin{array}{l}\text { organic } \\
\text { matter }\end{array}$ & carbonates \\
\hline & & & \multicolumn{2}{|c|}{$\%$ of the entire sample } \\
\hline \multirow[t]{5}{*}{ Loose sand } & 100 & 0 & 0.00 & 0.00 \\
\hline & 98 & 2 & 0.84 & 0.18 \\
\hline & 96 & 4 & 1.67 & 0.37 \\
\hline & 94 & 6 & 2.51 & 0.55 \\
\hline & 92 & 8 & 3.34 & 0.73 \\
\hline \multirow[t]{2}{*}{ Sand } & 90 & 10 & 4.18 & 0.92 \\
\hline & 87 & 13 & 5.43 & 1.19 \\
\hline \multirow[t]{2}{*}{ Loamy sand } & 85 & 15 & 6.27 & 1.38 \\
\hline & 80 & 20 & 8.36 & 1.83 \\
\hline \multirow[t]{3}{*}{ Sandy loam } & 70 & 30 & 12.54 & 2.75 \\
\hline & 67 & 33 & 13.79 & 3.03 \\
\hline & 65 & 35 & 14.63 & 3.21 \\
\hline \multirow[t]{2}{*}{ Loam } & 45 & 55 & 22.99 & 5.05 \\
\hline & 25 & 75 & 31.35 & 6.88 \\
\hline Silt loam & 5 & 95 & 39.71 & 8.72 \\
\hline
\end{tabular}

The second group were samples with an admixture of organic matter mixed with the clay and silt fraction. Organic matter was obtained from the humus horizon of Brunic Arenosol. The sampled material was dried and sieved through a sieve with a mesh of $1 \mathrm{~mm}$. Then it was boiled for part of organic matter soluble in water to remain in the suspension separated from mineral sediment remaining on the bottom. The suspension was subject to the evaporation process and sieved through a sieve with mesh below $0.05 \mathrm{~mm}$. The content of organic carbon in the suspension amounted to $41.8 \%$ according to Tiurin's method (37.8\% by means of the loss of ignition method). Measurements of organic carbon contentwere performed in three repetitions in accordance with the methodology (Przewodnik metodyczny 1999, Ostrowska et al. 1991).

The third group were samples with calcium carbonate. They were formed by adding to the sand fraction the clay and silt fractions originating from loess. After drying, the obtained material was ground in a mortar, and then sieved through a sieve with mesh $0.05 \mathrm{~mm}$. The content of calcium carbonate was determined by means of Scheibler's method, and the result averaged from three repetitions amounted to 9.174\% (Bednarek et al. 2005).
A total of 45 samples were prepared (15 control samples, 15 samples with organic matter, and 15 with calcium carbonate) for which determinations were performed by means of the areometric method. All measurements were performed in three repetitions, providing a total of 675 measurements by means of an areometer.

\section{Grain size composition of prepared samples}

In all of the prepared samples, the weight content of sand and silty-clayey fraction remained in an unchanged proportion. They differed in terms of content of admixtures. In addition to the determined ratio between grain of the sandy and silty-clayey fraction, also the percent contribution of the sandy material itself and fractions within silt and clay was determined. This permitted qualifying samples to particular granulometric groups (Table 2). Each of the 15 samples within the following groups: control, with organic matter, and with calcium carbonate - included 6 corresponding with the granulometric group of loose sand, 2 - sand, 2 - loamy sand, 2 - sandy loam, 2 loam, and 1- silt loam. The selection of subfractions was the result of the analysis of their contribution in the most common soils of Poland. Hence the proportions correspond with particular and natural formations determined based on the Atlas of Polish Forest Soils (Brożek and Zwydak 2010).

Granulometric groups' determination of the analysed formations is only of informative importance. The determination of the groups employed sand corrections. The cause of the considerable dilemma in the determination of granulometric groups was the discrepancy between the content of sand resulting from the preparation of the sample and content resulting from the performed analysis by means of the aerometric analysis with sand correction and application of the sieve-weight method for sand fractions (ex post). In this case, the latter solution was adopted in order to permit referring the analysed samples to other analyses. Samples representing particular granulometric groups were classified as if no experiment was conducted.

\section{STUDY RESULTS AND DISCUSSION}

As was already mentioned, the basic problem in the areometric analysis is the effect of the variable density of the medium on particle deposition. It concerns the most evidently particles with greater grain diameters deposited among particles with smaller diameters forming a medium with variable density (suspension). Due to the long time of remaining in the suspension of so-called floating particles 
$(<0.02 \mathrm{~mm}$ in diameter), based on their content and in supplementation of colloidal clay (diameter below $0.002 \mathrm{~mm}$ ), M. Prószyński (1949) constructed charts referring to the basic granulometric groups. Their basic function is the determination of the deposition's time of large particles, because the smallest particles falling in the surrounding of a "clear" water medium have relatively uniform conditions of deposition. In the conducted experiment concerning the effect of organic matter and calcium carbonate, representing particles from the smallest size ranges, the effect of such admixtures will also be manifested in a change in the conditions of larger particles' deposition - sandy fraction. The consequence was the application of a bi-polar system expressing the ratio between the content of sand fractions on the one hand, and the supplementing accumulated content of silt and clay fractions on the other. It would seem that results of the measurements of control samples with predefined content of fractions analysed by means of the areometric method should adjust to the predefined proportions of the percent distribution of particular fractions. It turned out that the determination of their grain size composition by means of the areometric method deviated from the predefined values (included in Table 2). An earlier, similar experiment showed that the areometric method is the most useful in the case of samples in which the analysed fractions are smaller than 0.1 or $0.25 \mathrm{~mm}$ in diameter (Cholewa 2013). Analysing the entire fraction range of sand, silt and clay fractions, the occurrence of considerable deviations between the predefined proportions and results of the aerometric analysis was therefore expected. The issue of the organic matter and carbonate admixture's impact on the effects of measurements was related to adding highly dispersed substances increasing the density of the medium for the falling sandy particles. Organic matter also had a substantial effect on the mineral particles rate of deposition, particularly the largest ones, due to its low density in comparison to the mineral composition of the soil. The assumed density of the mineral composition was $2.65 \mathrm{~g} \cdot \mathrm{cm}^{-3}$, and organic matter $-1.1 \mathrm{~g} \cdot \mathrm{cm}^{-3}$ (Zawadzki (ed.) 1999). Carbonate admixture increased the density of the water medium through partial transition to solution and an increase in the concentration of the finest particles in the suspension. The obtained results of measurements by means of an areometer were compared with values of samples prepared by weight. This provided the basis for the calculation of the difference in percent points (p.p.) between the predefined contents of fractions and control samples (with no admixtures) and samples with organic matter and carbonate admixtures.
All measurements were performed in three repetitions. This provided the basis for the determination of the repeatability of obtained results (variability coefficient). The greatest variability of measurements concerned control samples. The variability coefficient for this group amounted to $1.72 \%$. Measurements of samples with organic matter showed variability at a level of $1.34 \%$, and with carbonates only $1.18 \%$. The obtained results did not differ significantly. Measurements in the control group were performed first, and those for samples containing carbonates last. No effect of admixtures on the repeatability of measurements was recorded. Only a slight variability was observed within particular fractions. It ranges from $1.13 \%$ for the third measurement (threshold grain diameter $0.02 \mathrm{~mm}$ ) to a maximum of $1.7 \%$ for the fourth measurement (threshold grain diameter $0.005 \mathrm{~mm}$ ). Due to the small differences, it cannot be determined whether any of the measurements shows higher variability than the remaining ones. Surprisingly, the first measurement (threshold grain diameter $0.1 \mathrm{~mm}$ ), considered the most difficult due to the very short time (a dozen seconds), was characterised by variability at a level of only $1.43 \%$. Random error of the areometric method in the course of the performed measurements can therefore be determined at a level of $1-2 \%$ of read values (notice that it is not equivalent to the determination of relative error). The variability of results of determinations in the case of a single sample below $2 \%$ suggested due diligence in the performance of determinations. It permits neglecting minor random errors and focusing on several times larger differences systematic in character, genetically related to the essence and assumptions of the method.

\section{Analysis of results}

In control samples - no admixtures (Fig. 1), an increased content of sand fractions in comparison to the determined composition occurred in 9 out of 15 cases, covering samples with a content of the siltyclayey fraction higher than $13 \%$. In the range of silt and clay content of $13-20 \%$, the overrepresentation od sand resulting from aerometric measurements was limited to 2 percent points. In the case of a higher content of silt and clay (more than 20\%) - the overrepresentation successively increased to 11 percent points). A pattern was therefore determined that the more silty-clayey fraction is contained in a sample, the more overrepresentation of the sand fraction is recorded (Table 1). In four cases representing more sandy samples (loose sand or sand), with a total of the silt and clay content up to $6 \%$, results of measurements showed a deficiency of the sand fraction 
FIGURE 1. Differences between areometric measurements and predefined contents of the sandy and silty-clayey fraction in control samples

(Fig. 1). The deviation from the actual state in the samples is not very high. It does not exceed 2 p.p. The smallest measurement errors were observed for samples with a content of the siltyclayey fraction from 6 to $13 \%$.

In samples with organic matter (Fig. 2, Table 2), the ratio of the sandy fraction to the silty-clayey fraction is similar as in the case of control samples. In samples with a higher content of sand, results of measurement by means of an areometer provided overestimated values of the finest fraction, and in silty samples an increased content of the sand fraction was observed. In comparison to control samples, a shift of the overrepresentation of silty-clayey and sandy fractions was observed. The excess of the silt and clay fractions occurs in samples with a content of the sand fraction above $85 \%$. The range of the overrepresentation reaches 3 percent points (for a sample with a content of the sand fraction of $98 \%$ ). The research confirmed the effect of the organic matter content on the state of the medium in which sedimentation od particles occurs resulting in the underestimation of

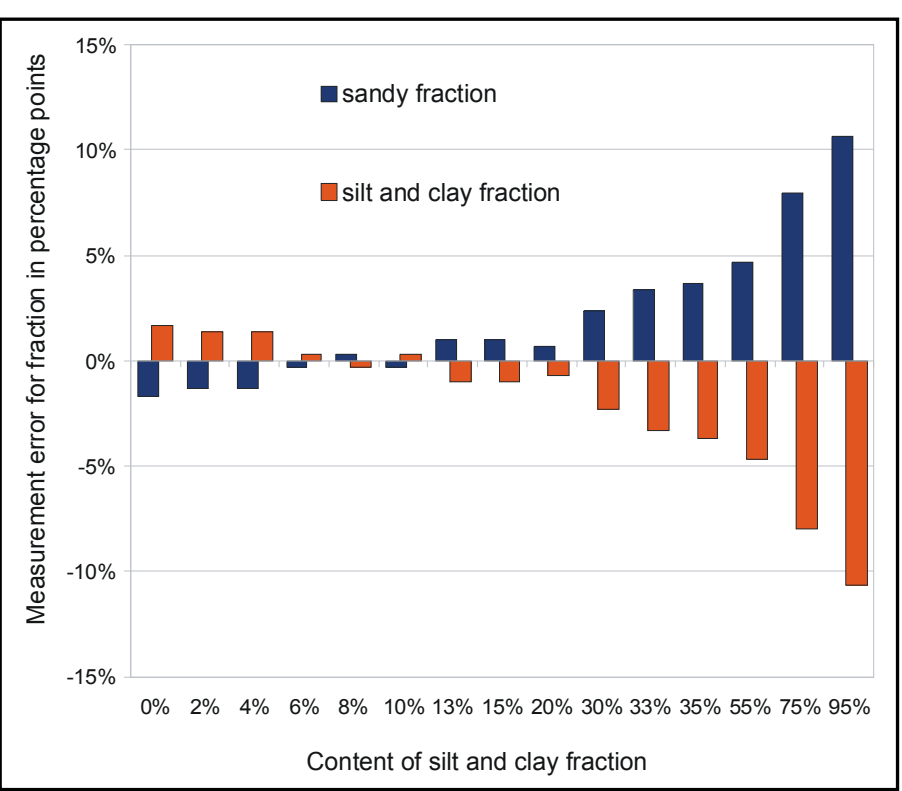

coarser (sandy) fractions falling slower, in denser suspension, with prolonged times characteristic of finer fractions. In the case of sandy fractions, the addition of organic matter itself (the finest fractions of colloidal clay) translates into an increase in the content of fine fractions. In this case, results of the measurements considerably differ from the predefined proportions due to the addition of organic matter. In the range of content of the silty-clayey fraction between 8 and $20 \%$, a compensation of two opposite tendencies occurs. Mutually cancelling measurement errors do not exceed 3 p.p. A particularly high overrepresentation of the sand fraction (from 7 to 13 p.p. in comparison to the determined granulometric composition) was recorded for samples with the content of the silt and clay fractions above 55\%. Samples with a high contribution of fine fractions will be therefore underestimated in terms of this fraction when they

FIGURE 2. Differences between areometric measurements and predefined contents of the sandy and silty-clayey fraction for samples with organic matter 


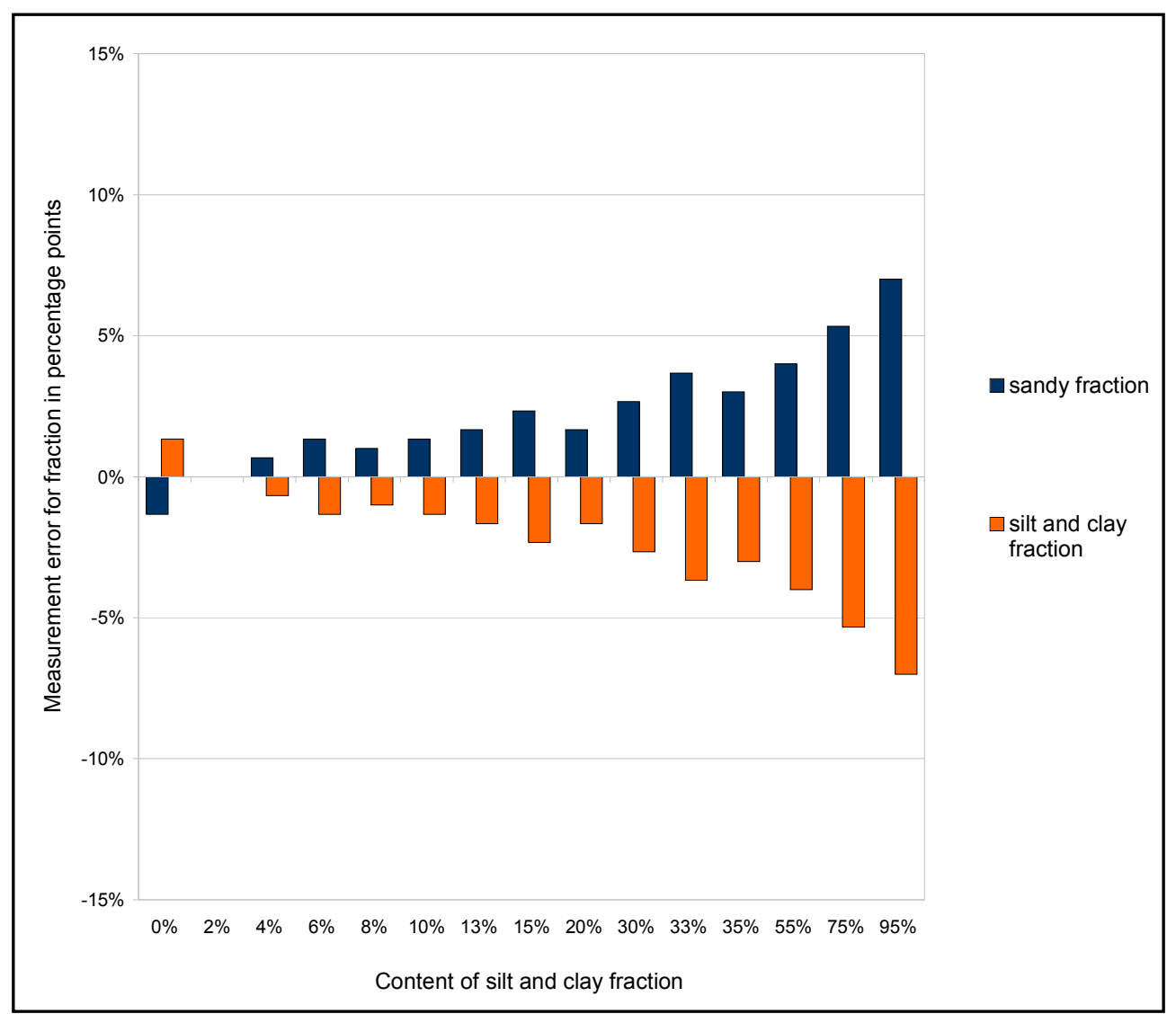

FIGURE 3. Differences between areometric measurements and predefined contents of the sandy and siltyclayey fraction for samples with calcium carbonate contain organic matter. This is a different result than expected.

In the case of samples containing calcium carbonate, in 13 out of 15 of them, overestimation of the content of the sandy fraction was observed in comparison to the predefined grain size composition (Fig. 3, Table 2). An admixture of carbonates caused underestimation of the contribution of sandy fractions by 2 p.p. only in relation to sandy samples. An addition of carbonate has a more uniform effect than an addition of organic matter. Practically throughout the range of the analysed contents, along with an increase of the contribution of the silty-clayey fraction (containing calcium carbonate), a gradual increase in the overrepresentation of the sandy fraction up to 7 percent points was observed for samples with a negligible contribution of the sandy fraction. A reversal of the tendency occurred in the case of a sample with a content of silt and clay of $2 \%$ (Fig. 3). This may be the coagulating effect of calcium carbonate. The deviation of the obtained values from the determined grain size composition is almost twice lower than in control samples or samples with organic matter. In laboratory practice, a greater importance should be placed on the removal of organic matter from samples than carbonates. The procedures of application of the areometric method developed in particular centres assume the removal of both organic matter and carbonates before proper measurement (e.g. Wrocław centre - University of Life Sciences). Paradoxically, an addition of calcium carbonate compensates for the error of the areometric method itself related to the overestimated amount of the sand fraction, particularly for silt samples.

Analysis of the impact on admixtures in granulometric groups (Table 3 ). In samples with the lightest composition (up to $8 \%$ of the silt and clay fractions -5 samples), differences in underestimations and overestimations of aerometric determinations in comparison to the experimentally predefined contributions were not significant. They were both positive and negative, but they did not exceed 1.5 p.p., which can be qualified as the specificity of the method. In this group of samples, the maximum content of organic matter amounted to $3.3 \%$, and carbonates $-0.73 \%$. The effect of admixtures was negligible.

In the case of samples with sand and loamy sand grain composition, the differences, particularly for samples with organic matter, were significant. The greatest disproportion occurred for fraction $0.05-0.02 \mathrm{~mm}$ (on average -4.6 p.p.) and for the clay fraction $<0.002 \mathrm{~mm}$ (on average +6.14 p.p.). For samples with calcium carbonate, the differences are again very low, not exceeding 1.5 p.p. For sandy loam, loamy, and silt, 
the tendencies are identical as in the group described earlier. For samples with organic matter, aerometric measurements show a deficiency of fraction $0.05-0.02 \mathrm{~mm}$ (on average 11.73 p.p.) and excess of fraction below $0.002 \mathrm{~mm}$ (on average +20.13 p.p.). For other fractions, the differences amount to more than 2 percent points. It is worth emphasising that the difference in the contribution of the silty fraction increases almost in a linear way depending on the content of organic matter in the sample (Fig. 4). Undoubtedly, however, for samples containing more than $5 \%$ of organic matter, errors are too large to be ignored.

Among samples containing calcium carbonate with a composition corresponding with sandy loam, loamy, and silt, differences were determined in the content of fractions amounting to 3 percent points. For samples with the highest content of carbonates (of more than 5\%), the contribution of fractions larger than $0.05-0.006 \mathrm{~mm}$ grows, and decreases for fractions below $0.006 \mathrm{~mm}$ (in particular below $0.002 \mathrm{~mm})$. For the "most" carbonate sample $(8.72 \%$ calcium carbonate), the deficiency of silt amounted to 7.66 p.p. This confirms that calcium carbonate contributed to an increase in grain diameter through coagulation. Due to this, at a value of more than 5\% of calcium carbonate, the areometric analysis should not be conducted without decalcification.

The high correlation of the controlled content of organic matter and measured content of the silty-clayey fraction, with the assumption that the entire humus is included in colloidal clay, suggests an almost $80 \%$ identification of the humus as clay (the remaining more than $20 \%$ is the silt fraction). Should we additionally assume that the mineral part of samples also

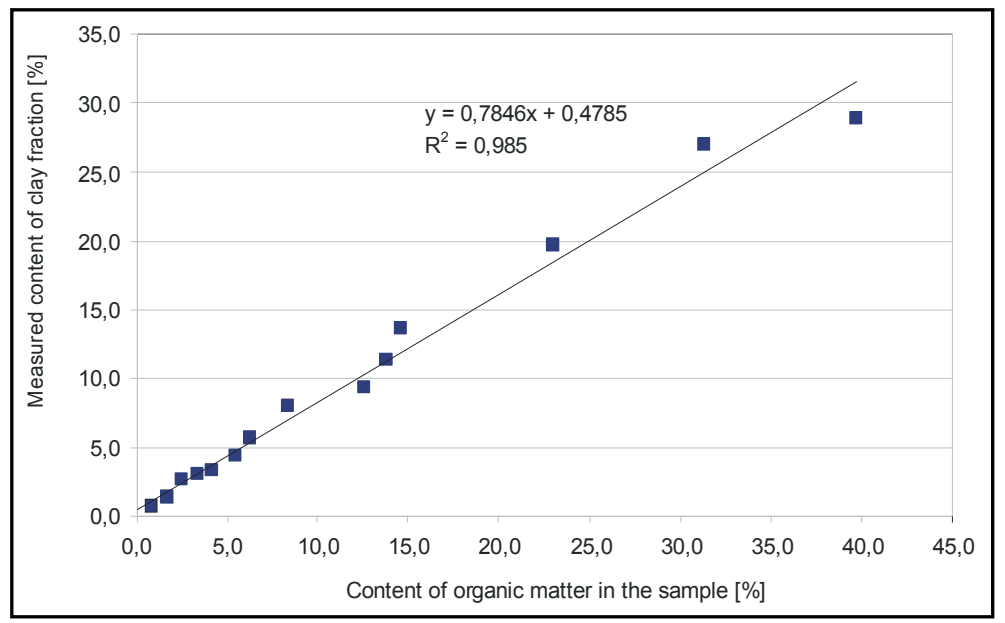

contains the clayey fraction, the underestimation of humus will prove even greater. It is difficult to unambiguously explain this dependency. In addition to the mismatch of the method itself with the identification of samples with organic matter, the correlations can also be explained by combining particles of humus with mineral particles representing silt and clay, therefore increasing the size of grains and consequently the rate of deposition. Such a phenomenon would prove unusually effective in the case of adding information on the already mentioned more than twice lower density of organic matter than mineral matter, which causes longer persistence in the suspension than that of analogical mineral particles. Therefore, the effectiveness of combining of organic matter with mineral particles must be even higher than would result from the earlier analysis.

The analytical procedures were completed with controlling the sand fraction by the sieve method after areometric determinations. In this case, the same method was applied to control the predefined contributions of sand before and after the areometric analysis (Table 4). It turned out that analytical procedures were not neutral towards the stability of contributions of larger fractions. Apart from one case, a decrease in the contributions of sand after boiling, multiple stirring, etc. was observed.

FIGURE 4. Dependency between the content of organic matter in a sample and measured content of the silty-clayey fraction 
TABLE 4. Comparison of predefined contents of sand fractions with contents determined by means of the sieve method after performing the areometric analysis

\begin{tabular}{|c|c|c|c|c|c|c|}
\hline \multirow[t]{2}{*}{$\begin{array}{l}\text { Predefined } \\
\text { content of } \\
\text { sands in } \\
\text { each sample }\end{array}$} & \multicolumn{3}{|c|}{$\begin{array}{l}\text { Content of sand determined } \\
\text { in a sample by means } \\
\text { of the sieve method after } \\
\text { the aerometric analysis } \\
\text { in a sample }\end{array}$} & \multicolumn{3}{|c|}{$\begin{array}{l}\text { Loss of content of sand after } \\
\text { the aerometric analysis } \\
\text { in comparison to predefined } \\
\text { contents in a sample }\end{array}$} \\
\hline & control & $\begin{array}{l}\text { with } \\
\text { organic } \\
\text { matter }\end{array}$ & $\begin{array}{l}\text { with } \\
\text { carbonates }\end{array}$ & control & $\begin{array}{l}\text { with } \\
\text { organic } \\
\text { matter }\end{array}$ & $\begin{array}{l}\text { with } \\
\text { carbonates }\end{array}$ \\
\hline \multicolumn{7}{|c|}{$\%$} \\
\hline 100 & 97.25 & 98.00 & 96.75 & 2.75 & 2.00 & 3.25 \\
\hline 98 & 95.75 & 95.00 & 95.25 & 2.25 & 3.00 & 2.75 \\
\hline 96 & 94.00 & 93.50 & 94.25 & 2.00 & 2.50 & 1.75 \\
\hline 94 & 92.00 & 90.75 & 92.00 & 2.00 & 3.25 & 2.00 \\
\hline 92 & 90.00 & 89.25 & 89.50 & 2.00 & 2.75 & 2.50 \\
\hline 90 & 88.00 & 87.50 & 88.25 & 2.00 & 2.50 & 1.75 \\
\hline 87 & 84.25 & 83.75 & 84.25 & 2.75 & 3.25 & 2.75 \\
\hline 85 & 82.50 & 81.75 & 83.25 & 2.50 & 3.25 & 1.75 \\
\hline 80 & 77.75 & 77.75 & 77.75 & 2.25 & 2.25 & 2.25 \\
\hline 70 & 65.25 & 67.50 & 67.75 & 4.75 & 2.50 & 2.25 \\
\hline 67 & 63.25 & 65.50 & 68.75 & 3.75 & 1.50 & -1.75 \\
\hline 65 & 60.25 & 62.00 & 63.50 & 4.75 & 3.00 & 1.50 \\
\hline 45 & 42.00 & 43.00 & 43.75 & 3.00 & 2.00 & 1.25 \\
\hline 25 & 23.75 & 23.75 & 23.50 & 1.25 & 1.25 & 1.50 \\
\hline 5 & 5.00 & 5.00 & 5.00 & 0.00 & 0.00 & 0.00 \\
\hline
\end{tabular}

The very coarse sand fraction $(2-1 \mathrm{~mm})$ showed a relatively small deviation from the predefined value (within $+/-0-1.5$ p.p.). The coarse sand fraction (1$0.5 \mathrm{~mm}$ ) was characterised by a considerably higher difference, often exceeding 5 p.p. For medium sand (grain diameter $0.5-0.25 \mathrm{~mm}$ ), a loss was recorded, lower than in the case of coarse sand (for 4 out of 45 samples its maximum amounted to 5 p.p.). For all samples, the contribution of coarser grains decreased. This may result from measures performed while preparing the samples. Grains combined in aggregates could be retained on sieves or be subject to physical (and/or chemical) destruction during the analytical procedure (particularly during mixing of cylinders - each sample was stirred several times). Coarser grains certainly collided and could fall apart into smaller ones. This is particularly confirmed by an increased content of the fine sand fraction $(0.25-0.1 \mathrm{~mm})$. In samples with organic matter, the organic sand fraction showed no considerable deviations from the actual state. The differences did not exceed 1.5 percent point. In the case of samples with calcium carbonate within the coarse fraction (very coarse sand), a loss exceeding even 5 p.p. was observed. In the case of the coarse sand fraction, its content increased for 14 out of 15 samples with carbonates. This may suggest the development of carbonate capsules on grains and aggregates.
The effect of the analysed changes expressed in a decrease in the content of the sand fractions further strengthens the overrepresentation of sands in a transition to heavier granulometric groups.

The presented amounts of losses (up to $5 \%$ ) shed some light on the possibility of preparation of samples for areometric analysis, after earlier sieving of the sand fractions. Measurements by an areometer become more stable in that case, because firstly they are performed after more than half a minute (first measurement for a substitute diameter of $0.05 \mathrm{~mm}$, in the case of sieving sands above $0.1 \mathrm{~mm}$ ) or after $10 \mathrm{~min}$ (in the case of sieving sands with a substitute diameter higher than $0.05 \mathrm{~mm}$ ), and secondly - the fractions subject to the aerometric analysis would have long stable times of deposition. The results of the conducted experiments, however suggest retaining of a part of the silt and clay fractions on the sieves, artificially leading to the overestimation of the contributions of sand determined before the areometric analysis. The entire process of sample preparation for and during the areometric analysis facilitates further, more precise sieve analysis of sand fractions. Moreover, preparation of a sample devoid of sand fractions for areometric analysis when it contains e.g. $10 \%$ silt and clay requires sieving of almost $0.5 \mathrm{~kg}$ of soil. Guidelines related to the selection of a particular scenario in the discussed problem would require further experiments focusing on this issue.

\section{CONCLUSIONS}

Based on the performed experiment, it was determined that the admixture of organic matter and calcium carbonate considerably affects the accuracy of measurements of the grain size composition by means of Cassagrande's areometric method in modification by Prószyński, particularly through:

- overestimation of the sand fraction content of the sand fraction, for samples containing more siltyclayey fraction,

- overestimation of the content of the silty-clayey fraction, particularly for samples containing more sandy fraction, 
It was also determined that:

- large grains (sand fraction), as a result of multiple stirring, are subject to breakdown into smaller ones,

- content of calcium carbonate influences the development of capsules and aggregates, providing underestimated results of the sand fraction.

The performed experiment permitted the determination of threshold values of contents of carbonates $(10 \%)$ for which their removal before the performance of the analysis is absolutely necessary for the deviations of the obtained values not to exceed $2 \%$ in comparison to those controlled in the experiment. The effect of organic matter is non-uniform within particular groups. The furthest reaching conclusion in reference to the areometric analysis is the recommendation of absolute mineralisation (removal of organic matter), similarly as the performance of decalcification (removal of carbonates). There is no certainty, however, whether laboratory procedures through which organic matter and carbonates are removed will not lead to the destruction of mineral particles..

\section{REFERENCES}

Bartkowiak A., 2011. Uziarnienie części mineralnej niejednorodnych osadów węglanowych oraz ich skład chemiczny na przykładzie gleb Basenu Unisławskiego. Roczniki Gleboznawcze - Soil Science Annual 62(4): 199-210.

Bednarek R., Dziadowiec H., Pokojska U., Prusinkiewicz Z., 2005. Badania ekologiczno-gleboznawcze. PWN, Warszawa.

Braun B., 2010. Właściwości gleb użytkowanych rolniczo w pasie Pojezierza Pomorskiego. Probl. Ekologii Krajobrazu 26: 231243.

Braun B., 2011. Współczesne zmiany właściwości gleb rolniczych w krajobrazie młodoglacjalnym. Prace i Studia Geograficzne 46: 93-106.

Brogowski Z., Kwasowski W., Madyniak R., 2014. Calculating particle density, bulk density, and total porosity of soil based on its texture. Soil Science Annual 65(4): 139-149.

Brożek S., Zwydak M., 2010. Atlas gleb leśnych Polski. Centrum Informacyjne Lasów Państwowych, Warszawa.

Cholewa K., 2013. Wpływ frakcji piasku na opadanie frakcji drobniejszych w metodzie Casagrande'a w modyfikacji Prószyńskiego. WGiSR UW, manuscript.

Drzymała S., Mocek A., 2004. Uziarnienie różnych gleb Polski w świetle klasyfikacji PTG, PN-R-04033 i USDA. Roczniki Gleboznawcze - Soil Science Annual 55(1): 107-115.

Frankowski Z., Grabowski D., 2006. Geologiczno-inżynierskie i geomorfologiczne uwarunkowania erozji wąwozowej w lessach w rejonie Kazimierza Dolnego (wąwóz Opolska Droga. Przeg. Geol. 54(9): 777-823.

Gworek B., Brogowski Z., Degórski M., Wawrzoniak J., 2000. Zmiany właściwości fizyko-chemicznych niektórych gleb Białowieskiego Parku Narodowege. Roczniki Gleboznawcze - Soil Science Annual 51: 87-99.
Kabała C., Buczak M., Gałka B., Chodak T., 2010. Antropogeniczne przekształcenia i klasyfikacja gleb parku dworskiego we Wrocławiu-Pawłowicach. Roczniki Gleboznawcze - Soil Science Annual 61: 69-77.

Konecka-Betley K., 2009. Złożona geneza gleb płowych (lessivés). Rocz. Gleb. 60: 113-128.

Lasota J., Błońska E., Zwydak M., Wanic T., 2014. Rola uziarnienia gleb w ocenie jakości siedlisk górskich. Leśne Prace Badawcze 75(3): 253-262.

Lejzerowicz A., Wysocka A., 2016. Osady polodowcowe w żwirowni w Paplinie (Wysoczyzna Rawska) w świetle badań tekstualnych. Landform Analysis 31: 3-16.

Licznar M., Licznar S.E., Drozd J., Weber J., 2009. Zmiany związków humusowych w sadach utrzymywanych w wieloletnim ugorze herbicydowym. Roczniki Gleboznawcze - Soil Science Annual 60: 60-68.

Loveland P.J., Whalley W.R., 2001. Particle size analysis, in: Soil and environmental analysis physical method, (eds. K.A. Smith, Ch.E. Mullins). Marcel Dekker Inc.

Musztyfaga E., Kabała C., 2015. Lithological discontinuity in Glossic Planosols (Albeluvisols) of Lower Silesia (SW Poland). Soil Science Annual 66(4): 180-190.

Orzechowski M., Smólczyński S., Długosz J., Pozniak P., 2014. Measurements of texture of soils formed from glaciolimnic sediments by areometric method, pipette method and laser diffraction method. Soil Science Annual 65(2): 72-79.

Ostrowska A., Gawlińska S., Szczubiałka Z., 1991. Metody analizy i oceny właściwości gleb i roślin. Katalog. Inst. Ochrony Środowiska, Warszawa.

Polskie Towarzystwo Gleboznawcze, 2009. Particle size distribution and textural classes of soils and mineral materials classification of Polish Society of Soil Science 2008 (Klasyfikacja uziarnienia gleb i utworów mineralnych - PTG 2008). Roczniki Gleboznawcze - Soil Science Annual, 60(2): 5-16.

Polish Soil Classification (Systematyka gleb Polski), 2011. Roczniki Gleboznawcze - Soil Science Annual 62(3): 1-193.

Prószyński M., 1949. Sposoby rozbioru uziarnienia gruntu (gleby). Mikrotechnika, Warszawa (manuskrypt).

Przewodnik metodyczny do badań materii organicznej gleb, 1999. Dziadowiec H., Gonet S.S. (eds.). Prace Komisji Naukowych PTG, Warszawa.

Różański S., 2010. Skład granulometryczny różnych typów gleb $\mathrm{w}$ aspekcie ich genezy oraz zmian w klasyfikacji uziarnienie. Roczniki Gleboznawcze - Soil Science Annual 59(3): 100110.

Ryżak M., Bartmiński P., Bieganowski A., 2009. Metody wyznaczania rozkładu granulometrycznego gleb mineralnych. Acta Agrophysica 175.

Sewerniak P., 2008. Wstępne wyniki badań nad wpływem uziarnienia gleby na bonitację drzewostanów sosnowych w południowo-zachodniej Polsce. Roczniki Gleboznawcze - Soil Science Annual 59(3/4): 255-261.

Szymański W., Skiba S., 2007. Geneza i znaczenie poziomu fragipan w glebach płowych (Albeluvisols) Pogórza Karpackiego. Roczniki Bieszczadzkie 15: 267-284.

Zawadzki S. (ed.), 1999. Gleboznawstwo. PWRiL, Warszawa.

Received: October 24, 2017

Accepted: June 4, 2018

Associated editor: J. Rejman 


\section{Wpływ zróżnicowanej zawartości materii organicznej i węglanów na wyniki oznaczania składu granulometrycznego metodą areometryczną Casagrande’a w modyfikacji Prószyńskiego}

Streszczenie: Celem niniejszej pracy było określenie wpływu zawartości materii organicznej oraz węglanów na wiarygodność oznaczenia uziarnienia metodą areometryczną Casagrande’a w modyfikacji Prószyńskiego. Określenie udziału poszczególnych zakresów wielkościowych ziaren należy do podstawowych charakterystyk analizy gleb. Skład granulometryczny determinuje bowiem właściwości fizyczne gleby. Obecnie, pomimo różnorodności metod analizy oznaczenia uziarnienia, metoda opracowana przez Prószyńskiego jest nadal stosowana, zapewniając tym samym możliwość porównywania obecnie uzyskiwanych wyników $\mathrm{z}$ danymi archiwalnymi.

Za podstawowy problem w metodzie uznać należy określenie zmienności gęstości ośrodka, w którym opadają cząstki, w zależności od zróżnicowanego składu granulometrycznego badanych utworów, co jest pochodną naturalnej zmienności udziałów poszczególnych zakresów wielkościowych ziaren mineralnych (w tym szczególnie zawartości czasstek najdrobniejszych frakcji) oraz obecności domieszek zakłócających proces sedymentacji (najpowszechniej obecnych substancji organicznej i węglanów). W celu określenia ich wpływu przeprowadzono badania w formie eksperymentu na próbkach o zadanym składzie granulometrycznym oraz znanej - również zadanej - zawartości domieszek.

Eksperyment podzielono na dwa etapy: przygotowanie materiału wraz z preparacją próbek oraz właściwy pomiar metodą areometryczną. W pierwszej kolejności spreparowano frakcje piasku o znanej zawartości podfrakcji. Uzupełniono je określoną zawartością mieszaniny frakcji pylastej i ilastej, tworząc w ten sposób próbki kontrolne (bez domieszek). Drugą grupę stanowiły próbki z domieszką materii organicznej wymieszanej z frakcją pylasto-ilastą, a trzecią - próbki z węglanem wapnia wymieszanym z frakcją pylasto ilastą. Łącznie spreparowano 45 próbek ( 15 kontrolnych, $15 \mathrm{z}$ materią organiczną i $15 \mathrm{z}$ węglanem wapnia), dla których wykonano oznaczenia metodą kombinowaną (areometryczną Casagrande'a w modyfikacji Prószyńskiego - poniżej $0,05 \mathrm{~mm}$ oraz metodą sitowo-wagową - powyżej $0,05 \mathrm{~mm}$ ). Wszystkie pomiary wykonano w trzech powtórzeniach, co łącznie dało 675 pomiarów areometrem. W zespołach trzech próbek (kontrolna, z materią organiczną i z weglanami) wagowa zawartość piasku oraz frakcji pylasto-ilastej pozostawała w niezmienionej proporcji. Spreparowano 15 takich zespołów różniących się od siebie zawartością domieszek. Oprócz ustalonego stosunku pomiędzy ziarnami frakcji piaszczystej i pylasto-ilastej, ustalono również procentowy skład samego materiału piaszczystego i frakcji w obrębie pyłu i iłu, co pozwoliło zakwalifikować próbki do poszczególnych grup granulometrycznych.

Na podstawie przeprowadzonego eksperymentu stwierdzono, że domieszka materii organicznej i węglanu wapnia w znaczny sposób wpływa na dokładność pomiarów składu granulometrycznego przede wszystkim przez: zawyżenie zawartości frakcji piasku (w próbkach zawierających więcej frakcji pylasto-ilastej), zawyżenie zawartości frakcji pylasto-ilastej (zwłaszcza w próbkach zawierających więcej frakcji piaszczystej). Stwierdzono także, że: duże ziarna (frakcja piasku), na skutek wielokrotnego mieszania, ulegaja rozbiciu na mniejsze, zawartość węglanu wapnia wpływa na tworzenie się otoczek i agregatów, dając zaniżone wyniki najmniejszej frakcji piasku. Wykonany eksperyment pozwolił na wyznaczenie wartości granicznych zawartości węglanów (10\%), dla której niezbędne jest ich bezwzględne usunięcie przed wykonaniem analizy, aby odchylenia uzyskiwanych zawartości piasków nie były wyższe niż $2 \%$ od kontrolowanych eksperymentalnie. Wpływ materii organicznej natomiast jest niejednolity w obrębie poszczególnych grup mechanicznych. Najdalej idących wnioskiem w stosunku do analizy areometrycznej jest zalecenie bezwzględnej mineralizacji, podobnie jak przeprowadzenie dekalcyfikacji. Nie ma natomiast pewności czy procedury laboratoryjne, przez które pozbywamy się materii organicznej i węglanów, nie doprowadzają do destrukcji części minerałów.

Słowa kluczowe: analiza areometryczna, metoda sedymentacyjna, modyfikacja Prószyńskiego, materia organiczna, węglany, zawiesina 